\title{
Hypoglycaemic encephalopathy
}

\author{
Karim Mahawish
}

Department of Health in Aging, Tauranga Hospital, Tauranga, New Zealand

\section{Correspondence to} Dr Karim Mahawish, k.mahawish@nhs.net

Accepted 27 March 2016

\section{DESCRIPTION}

A 49-year-old man with a history of type 1 diabetes self-presented to hospital, with ataxia and memory impairment. Admission blood glucose was $1.9 \mathrm{mmol} / \mathrm{L}$. Using a combination of intravenous and orally administered glucose, the patient became euglycaemic 45 min later. Marked cognitive impairment was noted to persist several days into his admission. An MRI of the brain scan was performed, demonstrating numerous foci of restricted diffusion involving the anterior and posterior territories (figures 1 and 2), including the cortex, subcortical white matter, deep white matter and corpus callosum. Blood tests for autoimmune, inflammatory and thrombogenic conditions, telemetry, echocardiography and angiographic studies of the extra and intracranial vessels, failed to demonstrate evidence of a thrombotic cause. The presence of multiple territory changes involving deep and cortical regions in the absence of vascular pathology made hypoglycaemic encephalopathy the only explanation for the presentation and findings.

The patient was admitted for rehabilitation. One month into his admission, an Addenbrookes Cognitive Examination- $\mathrm{R}$ was undertaken, for which the patient scored poorly at $62 / 100$, with deficits predominantly affecting memory, verbal fluency and visuospatial ability. The patient had no insight into his difficulties. He was subsequently discharged with a comprehensive care package to the care of his partner.

Numerous MRI changes have been described in patients presenting with hypoglycaemic

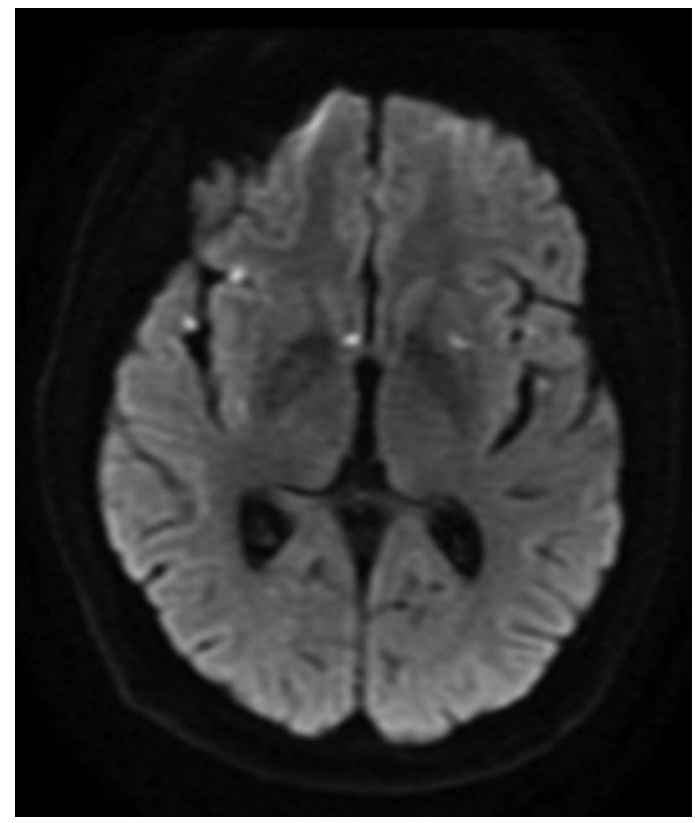

Figure 1 Multiple foci of restricted diffusion involving the anterior cortex, left basal ganglia and corpus callosum.

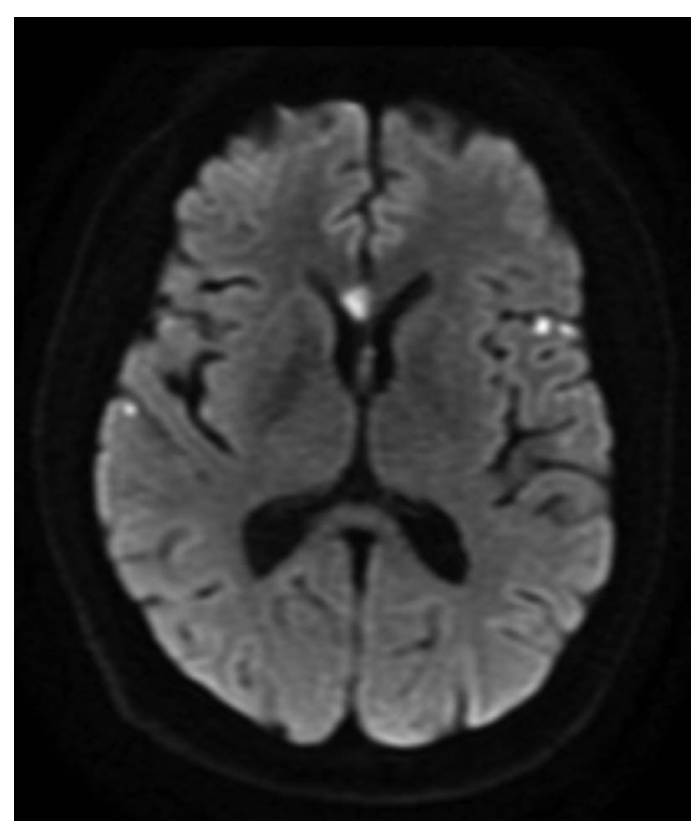

Figure 2 Multiple foci of restricted diffusion involving the anterior cortex, and corpus callosum.

encephalopathy. MRI findings are related to the duration of hypoglycaemia; bilateral cortical lesions are observed in severe cases and associated with longterm neurological sequelae, while transient unilateral lesions are seen in those with milder symptoms. ${ }^{1}$

\section{Learning points}

- Simultaneous multiterritory 'infarcts' on brain imaging are most commonly due to cardiogenic emboli (eg, secondary to atrial fibrillation).

- Other rarer differentials should be considered, for example, hypoglycaemia, as the management plan is significantly different. In this case, antithrombotic therapy was discontinued and emphasis placed on more optimal diabetes control.

Contributors KM was responsible for performing the literature search, writing up the case and seeking patient consent.

Competing interests None declared.

Patient consent Obtained.

Provenance and peer review Not commissioned; externally peer reviewed.

\section{REFERENCE}

1 Yong AW, Morris Z, Shuler K, et al. Acute symptomatic hypoglycaemia mimicking ischaemic stroke on imaging: a systemic review. BMC Neurol 2012;12:139. 


\section{Images in...}

Copyright 2016 BMJ Publishing Group. All rights reserved. For permission to reuse any of this content visit http://group.bmj.com/group/rights-licensing/permissions.

BMJ Case Report Fellows may re-use this article for personal use and teaching without any further permission.

Become a Fellow of BMJ Case Reports today and you can:

- Submit as many cases as you like

- Enjoy fast sympathetic peer review and rapid publication of accepted articles

- Access all the published articles

- Re-use any of the published material for personal use and teaching without further permission

For information on Institutional Fellowships contact consortiasales@bmjgroup.com

Visit casereports.bmj.com for more articles like this and to become a Fellow 